\author{
A.P. Kireyev ${ }^{1}$ \\ International Monetary Fund, Washington, USA \\ J. Ferrer \\ International Monetary Fund, Washington, USA
}

\title{
Economic policies in a pandemic
}

Abstract. What economic policy space does a country have to respond to a crisis provoked by the Covid-19 pandemic? To assess this space, the article calculates the nominal policy space index as a sum of each country's fiscal space, monetary space, and reserve space. This nominal policy space is then adjusted for institutional features of individual countries to derive the effective policy space index. By way of illustration, the article applies the index to the Covid-19 crisis. It finds that at least 95 countries (about 11 percent of global GDP and 23 percent of population) have no or very limited policy space and may require emergency assistance.

Keywords: policy space, fiscal space, debt sustainability, foreign reserves, public debt, market access. JEL Classification: E61, F01, F42, H12.

DOI: $10.31737 / 2221-2264-2021-49-1-7$

\section{Introduction}

What economic policy space does a country have to respond to a crisis provoked by a pandemic? The unprecedented Covid-19 crisis has put this question at the forefront of the policy debate, as countries have scrambled to mobilize resource for an immediate short-term response. Government and central banks across the world have deployed stimulus packages to support their economies of nearly US $\$ 12$ trillion of fiscal policy support from governments and a massive liquidity injection by central banks. The size of such packages depended mainly on the economic policy space available to the authorities before the pandemic and institutional features of each economy.

The purpose of the paper is to propose a methodology to assess the economic policy space. The index would allow assessing the policy space available to each country for a short-term response to a catastrophic event, like the Covid-19 pandemic.

The paper builds on earlier research related to the components of policy space. For example, elements of policy space have been extensively explored by the IMF and other international institutions, such as the World Bank (for example, (Kose, Ohnsorge, 2019) and by academic researchers (Kentikelenis, Stubbs, King, 2016, 2020; Romer, Romer, 2018).

\section{Policy Space Components}

In this paper, policy space is defined as a country's ability to finance measures needed to respond to shocks in the short run. This response can be based on the use of existing or newly created instruments, own or borrowed resources, but in any case, should not undermine macroeconomic stability during the current year. Therefore, the policy space in this restricted and somewhat static definition depends on a country's own policies, for example, its fiscal and monetary policies, and the willingness of its partners to assist in times of difficulties, for example, by providing lending.

The short-term policy space concept can be presented in a matrix form. This is a $3 \times 5$ matrix, which reflects quantitative and qualitative components of policy space (Figure 1). Quantitatively, policy space should reflect at a minimum the country's fiscal space, monetary space, and reserve space. Qualitatively, the assessment of policy space under each of these components would depend on the country's national currency status (reserve currency or national currency), debt distress risk (low, moderate, high, in distress), its fiscal risk assessment (high, medium or low), its access to capital markets (full, limited or none), and its exchange rate regime (flexible, soft peg or hard peg). Thus, there are two different fiscal components in the policy space concept: fiscal space is measured quantitatively in percent of GDP; while fiscal risks are assessed mainly qualitatively involv-

\footnotetext{
${ }^{1}$ The views expressed are those of the author and do not necessarily represent the views of the IMF, its Executive Board, or IMF management. The paper draws on a broader study that will be published separately.
} 


\begin{tabular}{|c|c|c|c|c|}
\hline \begin{tabular}{|l} 
Nominal space indicator \\
Institutional environment \\
\end{tabular} & & Fiscal Space & Monetary space & Reserve space \\
\hline Currency status & $\begin{array}{l}\text { Reserve } \\
\text { National }\end{array}$ & & & \\
\hline Debt distress risk & $\begin{array}{l}\text { Low } \\
\text { Moderate } \\
\text { High } \\
\text { In distress }\end{array}$ & & & \\
\hline Access to capital markets & $\begin{array}{l}\text { Full } \\
\text { Limited } \\
\text { None }\end{array}$ & & & \\
\hline Exchange rate regime & $\begin{array}{l}\text { Flexible } \\
\text { Soft peg } \\
\text { Hard peg }\end{array}$ & & & \\
\hline
\end{tabular}

Key: Amplifies policy space Has neutral impact on policy space Partially restricts policy space Fully restricts policy space

Figure 1

Effective Policy Space Matrix

Source: Author's presentation.

ing substantial expert judgment.

"Nominal" and "effective" policy space should be distinguished. Nominal policy space is defined as the difference between a defined threshold and the observed policy indicator (e.g. debt to GDP, reserves as months of imports). Nominal space can be positive when the indicator is below the threshold or negative if otherwise. In contrast, effective policy space is nominal space adjusted for the country's specific institutional environment shown in the rows of Figure 1.

Fiscal space is the main quantitative component of policy space. The (IMF, 2018a) narrowly defines fiscal space as the room for undertaking discretionary fiscal policy by raising expenditure or reducing taxes relative to existing baseline without compromising market access and debt sustainability. The Fund explicitly states that any quantitative assessment should be based on a comprehensive approach and incorporate judgement (IMF, 2018b).

Fiscal space assessments are already conducted relative to benchmarks. All benchmarks are indicative. For example, for advanced economies, the debt level sustainability benchmark is $85 \%$ of GDP and the gross financing needs are $20 \%$ of GDP. For emerging market economies, the benchmarks are 70 and $15 \%$ of GDP correspondingly.

Borrowing space is a main contributor to fiscal space. As public debt sustainability closely depends on fiscal policy, borrowing space is closely linked to fiscal space. Thus, borrowing space is usually defined as a country's capacity to borrow without undermining debt sustainability (Table 1).

Due to lack of quantitative metrics for many countries, fiscal space in this paper is narrowly defined as borrowing space. Fiscal/borrowing space is calculated as the difference between a country's public debt-to-GDP ratio and the sustainability threshold defined by the average debt ratio of countries assessed to have low or medium fiscal risk which amounts to 70\% of GDP. For EMs and AEs, a similar threshold was used as it is the average debt-to-GDP ratio, at which a country is reclassified from medium to high fiscal risk in the vulnerability exercise.

Monetary space is the second quantitative 
Table 1

Debt sustainability thresholds for LICs

\begin{tabular}{|l|c|c|c|c|c|}
\hline \multirow{2}{*}{ Degree } & \multicolumn{2}{|l|}{$\begin{array}{l}\text { Present value of external debt in } \\
\text { percent of }\end{array}$} & \multicolumn{2}{|c|}{ External debt service in percent of $\begin{array}{l}\text { Present value of } \\
\text { public debt in } \\
\text { percent of }\end{array}$} \\
\cline { 2 - 6 } & GDP & Exports & Exports & Revenue & GDP \\
\hline \hline Weak & 30 & 140 & 10 & 14 & 35 \\
Medium & 40 & 180 & 15 & 18 & 55 \\
Strong & 50 & 240 & 21 & 23 & 70 \\
\hline
\end{tabular}

Source: IMF, 2020b.

component of policy space. Monetary space is conventionally defined as ability of central banks to change policy rates at their discretion to achieve their macroeconomic objectives. The existence of monetary policy space has been forcefully called into question by the zero bound on policy rates, prevailing in most advanced economies in the years post-global financial crisis.

In this paper, monetary space is defined as central banks' capacity to increase inflation. For countries with fixed exchange rates monetary space is set at zero. For other countries, relative to other possible definitions, this paper takes a broader approach to measuring monetary space - as the central bank's ability to engage in expansionary monetary policies in response to a crisis, without compromising price stability.

Reserve space is the third quantitative component of policy space. The concept of reserve space can be derived from the reserve adequacy metric. The traditional metrics, which remain broadly relevant and are routinely used for policy making, include import cover, the ratio of reserves to short-term debt, and the ratio of reserves to broad money. The import cover ratio is usually viewed as relevant for countries with relatively closed capital accounts, as it points at how long imports can be sustained in the event of a shock. Its traditional metrics have been based on months of prospective imports, with three months of import coverage and $100 \%$ cover of short-term debt with reserves as the most widely used standards of adequacy. Finally, for countries with large banking sector and very open capital accounts, the ratio of reserves to broad money has been used to capture capital flight risks, with the upper end of a prudent range for reserve holdings typically set at

\section{$20 \%$ (IMF, 2016b).}

In this paper, nominal reserve space is defined as the level of reserves exceeding the reserve adequacy level. Assuming that countries hold reserves only for precautionary purposes, reserves are considered adequate if the country maintains three or more months of the prospective value of imports of goods and services. This is used as the adequacy threshold.

\section{Institutional Environment}

Policy space critically depends on the institutional environment. Governments' capacity to have and increase policy space reflects institutional, structural and other policy constraints, in which they operate. For the purposes of this paper, five components of institutional environment are considered - the international status of the local currency (reserve currency countries (RCCs) vis non-RCCs), risk of debt distress, access to capital markets, exchange rate regime, and fiscal risk (Table 2).

The reserve currency status of the national currency amplifies policy space. Reserve currency is conventionally defined as a foreign currency held in significant quantities by central banks as part of their foreign exchange reserves. IMF Articles of Agreement do not define reserve currency directly, but they mention reserve assets. Also, the IMF publishes regularly Currency Composition of Official Foreign Exchange Reserves (COFER) (IMF, 2020a).

In this paper, RCCs are defined as the United States and countries in the Euro area. Their central banks issue reserve currencies (US dollar and Euro, respectively), their government repay their debts mainly in national currencies, 
Table 2

Policy Space Components

\begin{tabular}{|c|c|c|c|}
\hline Space indicator & & Definition & Unit \\
\hline \multirow{2}{*}{$\begin{array}{l}\text { Borrowing } \\
\text { space }\end{array}$} & Yes & Public debt-to-GDP ratio below $70 \%$ of GDP & \multirow{2}{*}{$\begin{array}{l}\text { Percent } \\
\text { of GDP }\end{array}$} \\
\hline & No & Public debt-to-GDP ratio above $70 \%$ of GDP & \\
\hline \multirow{2}{*}{ Monetary space } & Yes & $\begin{array}{l}\text { Inflation is lower than target or average non-RCC } \\
\text { target, if no target }\end{array}$ & \multirow{2}{*}{$\begin{array}{l}\text { Percent } \\
\text { of GDP }\end{array}$} \\
\hline & No & $\begin{array}{l}\text { Inflation is equal of above than target or average } \\
\text { non-RCC target }\end{array}$ & \\
\hline \multirow{2}{*}{ Reserve space } & Yes & Reserves above 3 months of imports & \multirow{2}{*}{$\begin{array}{l}\text { Percent } \\
\text { of GDP }\end{array}$} \\
\hline & No & Reserves below 3 months of imports & \\
\hline \multicolumn{4}{|c|}{ Institutional environment } \\
\hline \multirow{2}{*}{ Currency status } & $\begin{array}{l}\text { Reserve } \\
\text { currency }\end{array}$ & United Sates and Euro area countries & \multirow{2}{*}{$\begin{array}{l}\text { Amplified } \\
\text { space }\end{array}$} \\
\hline & $\begin{array}{l}\text { National } \\
\text { currency }\end{array}$ & All other countries & \\
\hline \multirow{4}{*}{$\begin{array}{l}\text { Debt distress } \\
\text { risk (LICs) }\end{array}$} & Low & $\begin{array}{l}\text { None of the debt burden indicators breaches their } \\
\text { respective thresholds under the baseline and stress } \\
\text { tests }\end{array}$ & \multirow{3}{*}{ Full space } \\
\hline & Moderate & $\begin{array}{l}\text { No indicator breaches the thresholds under } \\
\text { the baseline scenario, but at least one indicator } \\
\text { breaches it under the stress tests }\end{array}$ & \\
\hline & High & $\begin{array}{l}\text { Any debt burden indicator breaches its threshold } \\
\text { under the baseline, but the country does not face } \\
\text { any repayment difficulties }\end{array}$ & \\
\hline & In distress & $\begin{array}{l}\text { The country is experiencing difficulties in debt } \\
\text { servicing, arrears, ongoing or impending debt } \\
\text { restructuring }\end{array}$ & No space \\
\hline \multirow{3}{*}{$\begin{array}{l}\text { Access to capi- } \\
\text { tal markets }\end{array}$} & Full & $\begin{array}{l}\text { Moody's investment grade rating of Aaa to Baa3 (1 } \\
\text { to 10) }\end{array}$ & Full space \\
\hline & Limited & $\begin{array}{l}\text { Moody's non-investment grade rating of Ba1 to B3 } \\
\text { (11 to 16) }\end{array}$ & $\begin{array}{l}\text { Limited } \\
\text { space }\end{array}$ \\
\hline & None & $\begin{array}{l}\text { Moody's non-investment grade rating of Caal to C } \\
\text { (above 17) }\end{array}$ & No space \\
\hline \multirow{3}{*}{$\begin{array}{l}\text { Exchange rate } \\
\text { regime }\end{array}$} & Flexible & $\begin{array}{l}\text { Currencies with free floating and floating exchange } \\
\text { rate regimes }\end{array}$ & Full space \\
\hline & Soft peg & $\begin{array}{l}\text { Currencies pegged within horizonal band, stabi- } \\
\text { lized arrangements, crawling peg, and craw-like } \\
\text { peg }\end{array}$ & $\begin{array}{l}\text { Limited } \\
\text { space }\end{array}$ \\
\hline & Hard peg & $\begin{array}{l}\text { Currency board, no separate legal tender, conven- } \\
\text { tional peg }\end{array}$ & No space \\
\hline \multirow{3}{*}{ Fiscal risk } & Low & $\begin{array}{l}\text { Below the 25th percentile of fiscal risk index } \\
\text { distribution }\end{array}$ & Full space \\
\hline & Medium & $\begin{array}{l}\text { Between the 25th and } 50 \text { th percentiles of fiscal risk } \\
\text { index distribution }\end{array}$ & $\begin{array}{l}\text { Limited } \\
\text { space }\end{array}$ \\
\hline & High & $\begin{array}{l}\text { Above the } 50 \text { th percentile of fiscal risk index } \\
\text { distribution }\end{array}$ & No space \\
\hline
\end{tabular}

Source: Authors' presentation. 
can readily swap their nationals currencies for other currencies, and their currencies are widely accepted for international transactions. This is not the case, however, for the United Kingdom and Japan, where central banks have to keep substantial reserves in US dollars and Euros.

The risk of debt distress severely limits policy space. Under the Debd Sustainability Fgramework (DSF) (IMF, 2020b), for low-income countries (LICs) risk signals to debt sustainability are derived by comparing debt burden indicators with the indicative thresholds over a projection period. There are four ratings for the risk of external public debt distress: low risk, if none of the debt burden indicators breach their respective thresholds; moderate risk, if none of the debt burden indicators breach their thresholds, but at least one indicator breaches its threshold under the stress tests; high risk, if any of the external debt burden indicators breaches its threshold under the baseline scenario, but the country does not currently face any repayment difficulties; or in debt distress, when the country is already experiencing difficulties in servicing its debt.

Access to capital markets amplifies policy space. In principle, the capacity of countries to borrow from international capital markets increases their policy space. In a nutshell, if a country has access to capital market financing at a reasonable risk premium, it has fiscal/borrowing space; if not, the country is considered to have limited or no fiscal/borrowing space. The assessment of market access is often based on the sovereign bond spreads: the higher the spread, the higher the risk premium and therefore the lower market access.

In this paper, access to capital markets is measured by Moody's global ratings. The reason for the selection of Moody's over other ratings agencies is that Moody's country coverage is more comprehensive, and the ratings are more granular. These ratings on long-term obligation in foreign currency reflect opinions on the relative credit risk of fixed-income obligations with an original maturity of one year or more (Moody's, 2020). Most countries have Moody's ratings and are classified in three categories: full access (investment grade ratings), limited access (non-investment grade ratings with speculative elements) and no access (noninvestment grade ratings with obligations in or near default).

The exchange rate regime has an ambiguous impact on policy space. A fixed exchange rate regime severely limits policy space, whereas floating exchange rate regime amplifies it. Policy space would depend on the need to defend of a certain level of exchange rate. Countries with floating exchange rate regimes, where there is no explicit or implicit commitment to a specific level of exchange rate, have more policy space than countries with any form of managed exchange rates. IMF Annual Report on Exchange Arrangements and Exchange Restrictions (AREAER) (IMF, 2020e) provides information on the de jure exchange rate arrangements as described by the countries and the de facto arrangements, which are classified into three types and 10 categories. This paper follows the classification of exchange rate arrangements by types into hard pegs, soft pegs, and floating regimes.

Fiscal risks condition a country's ability to use its nominal fiscal space. Fiscal risks are factors that may cause fiscal outcomes to deviate from expectations or forecasts. Fiscal risks can arise from macroeconomic shocks or the realization of contingent liabilities - that is obligations triggered by an uncertain event (IMF, 2016c). High or even medium levels of fiscal risks can limit a country's access to international capital markets, as lenders will be wary of extending credit to countries experiencing high fiscal distress.

In this paper, the IMF's fiscal risk index is used as a measure of fiscal risk. The index is derived from the vulnerability exercise, an important part of the IMF's risk assessment architecture (Ahuja, Syed, Wiseman, 2017).

\section{Application to the Covid-19 Crisis}

Several groups of countries can be distinguished by effective policy space. The 187 countries included in the WEO database as of June 2020 (IMF, 2020f) can be classified into five groups by the decreasing level of available policy space (Figure 2). 


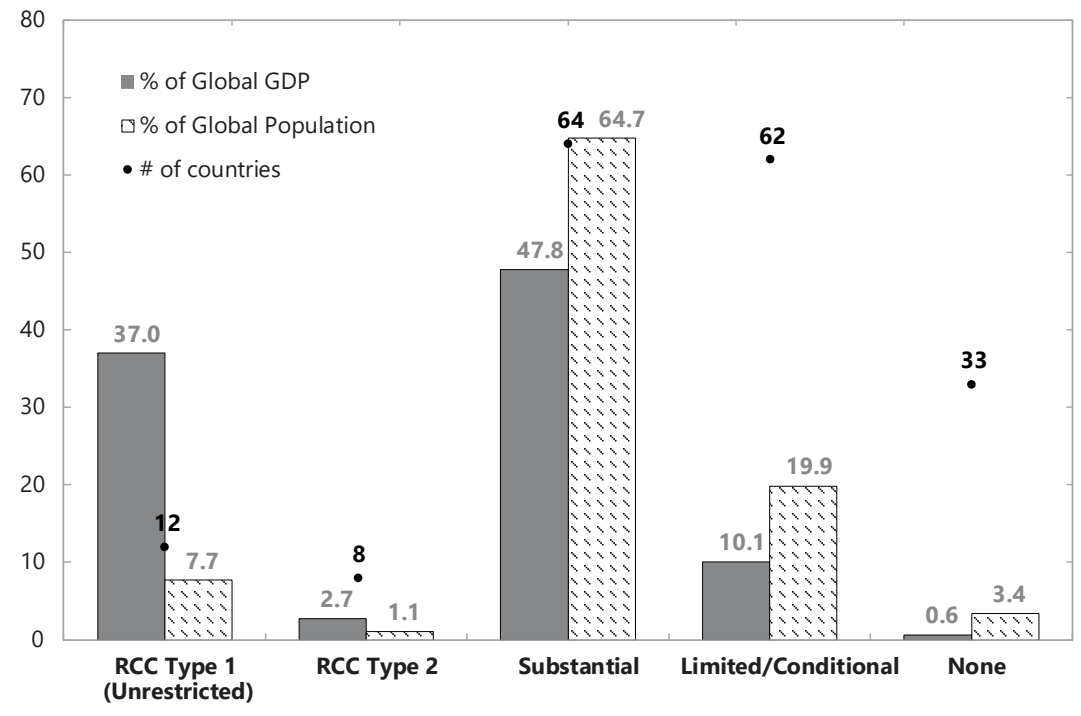

Figure 2

Application of our Policy Space Measure to Covid-19 Group Composition (in percent; number of countries)

Source: Author's calculations.

Group 1. Reserve currency countries with unrestricted policy space (Type 1). This group includes reserve currency countries (RCCs) with full access to capital markets and low fiscal risks. In the short run, countries in this group have unrestricted resources to fight any crisis, even comparable to the Covid-19 in magnitude. There are 12 countries in this group, all of them advanced economies, but they represent over one third of the global GDP and almost $8 \%$ of the world population.

Group 2. Reserve currency countries with somewhat restricted policy space (Type 2). This group includes RCCs with limited access to capital markets or medium to high fiscal risks. In the short run, countries in this group still have enough resources to fight any crisis but need to address mounting vulnerabilities that increase their fiscal risks and limit access to capital markets. This group includes only eight countries, all of them advanced economies, producing about $3 \%$ of the world GDP.

Group 3. Non-reserve currency countries with substantial policy space. Countries in this group are not RCCs but have considerable effective policy space, large enough to absorb in the short run all costs of the Covid-19 crisis or a similar-size negative shock. The 2020 cost of the crisis is defined as the average 2019-2020 loss in nominal policy space which amounts to $11 \%$ of GDP. A total of 64 countries accounting for $65 \%$ of global population producing roughly half of the global GDP can be included in this group. Many advanced economies with non-reserve currencies, as well as oil producers and other commodity exporters are included in this group.

Group 4. Non-reserve currency countries with conditional policy space. Countries in this group have either very limited or no effective policy space. The sub-group of countries with limited effective policy space includes countries with some positive effective space but that is still insufficient to cover all financing needs from the Covid19 crisis in the short run. This group includes 62 countries, accounting for $20 \%$ of global population and producing about $10 \%$ of the global GDP. The group is very diverse and includes advanced, middle-income and LICs, each of them facing country-specific problems that severely limit their policy space.

Group 5. Non-reserve currency countries with no policy space. This is a residual group, which includes all other countries with the policy space index equal to zero. Although its individual 
components may indicate some nominal space in particular areas, the institutional characteristics of these countries suggest that this space cannot be used. Countries in this group have effective policy space equal to zero and have no room even for conditional financing. They will have to rely on grants and donors willing to take substantial default risks. In addition, these countries have no or limited access to capital markets. Some 33 middle- and low-income countries, representing $0.6 \%$ of the global GDP and $3.4 \%$ of the global population are included in this group.

\section{Conclusions}

The effective policy space index is an addition to the policymakers' toolkit. The index can be used to take a snapshot of a country's readiness to address a catastrophic event akin the Covid19 crisis in the short run. It allows seeing the overall magnitude of policy space and its components available to the authorities. The index also can guide them in taking decisions on how to strengthen their effective policy space and use it rationally in case of need. Also, the index allows comparing policy space across countries under a single methodology useful for further aggregation to assess the potential financial needs for groups of countries and the world. Finally, the policy space index can also be included as an additional variable in analytical frameworks to examine options available to the authorities to react to unforeseen events, such as the Covid-19 pandemic.

\section{REFERENCES}

Ahuja A., Syed M., Wiseman K. (2017). Assessing country risk: Selected approaches. IMF Technical Notes and Manuals No. 17/08. Available at: https://www. imf.org / en / Publications / TNM / Issues /2017/06/01/Assessing-CountryRisk-Selected-Approaches-44959

IMF (2016b). Guidance note on the assessment of reserve adequacy and related considerations. Available at: https://www.imf.org/exter$\mathrm{nal} / \mathrm{np} / \mathrm{pp} / \mathrm{eng} / 2016 / 060316 . \mathrm{pdf}$
IMF (2018a). Assessing fiscal space: An update and stocktaking. IMF Policy Paper. April 11. Available at: https://www.imf. org / en / Publications / Policy-Papers / Issues /2018/06/15/pp041118assessingfiscal-space

IMF (2018b). Economic preparedness: The need for fiscal space. IMF Blog. June 28. Available at: https://blogs.imf.org/2018/06/27/ economic-preparedness-the-need-for-fiscal-space

IMF (2020a). Currency composition of official foreign exchange reserves. Available at: https://data. imf.org

IMF (2020b). Joint World Bank-IMF debt sustainability framework for low-income countries. Available at: https: / / www.imf.org/en/About/ Factsheets/Sheets/2016/08/01/16/39/ Debt-Sustainability-Framework-for-LowIncome-Countries

IMF (2020e). Assessing reserve adequacy (ARA) data set. Available at: https://www.imf.org/ external/datamapper/datasets /ARA

IMF (2020f). World Economic Outlook Databases. Available at: https://www.imf.org/en/ Publications /SPROLLs / world-economicoutlook-databases

Kentikelenis A., Stubbs T., King L. (2016). IMF conditionality and development policy space, 1985-2014. Review of International Political Economy, 23 (4), 543-582.

Kose M., Ohnsorge F. (2019). A decade after the global recession: Lessons and challenges for emerging and developing economies. World Bank.

Moody's (2020). Rating symbols and definitions. Moody's Investors Service. January. Available at: https://www.moodys.com/researchdocumentcontentpage.aspx?docid= PBC_79004

Romer C., Romer D. (2018). Phillips lecture why some times are different: Macroeconomic policy and the aftermath of financial crises. Economica, 85 (337), 1-40.

Поступила в редакиию 13.02.2021 


\section{А.П. Киреев}

Международный валютный фонд, Вашингтон, США

Х. Феррер

Международный валютный фонд, Вашингтон, США

\section{Экономическая политика во время пандемии}

Аннотация. Какое пространство для экономической политики имеет страна, чтобы отреагировать на Covid-19? Чтобы оценить это пространство, в статье рассчитывается номинальный индекс экономического пространства как сумма бюджетного пространства, денежного пространства и резервного пространства каждой страны. Это номинальное пространство затем корректируется с учетом институциональных характеристик отдельных стран для получения индекса әффективного экономического пространства. В качестве иллюстрации индекс применяется к кризису Covid-19. В статье показано, что по крайней мере 95 стран (около $11 \%$ мирового ВВП и $23 \%$ населения) не имеют экономической возможности реагировать на кризис или имеют очень ограниченное экономическое пространство и могут нуждаться в экстренной помощи.

Ключевые слова: пространство экономической политики, бюджетное пространство, устойчивость долга, иностранные резервы, государственный доле, доступ к рынкам.

Классификация JEL: E61, F01, F42, H12.

DOI: $10.31737 / 2221-2264-2021-49-1-7$

\section{J. Sapir}

EHESS-Paris, Centre for the Study of Industrialization Pattern (CEMI) -

\section{Is Eurozone accumulating a historic lag toward Asia in the COVID-19 context?}

Abstract. The COVID-19 epidemic has shaken the world and affected the global economy. Coming from China, this epidemic has hit different countries in a close succession. Western Europe and the Eurozone were severely hit by the pandemy. The so-called " $2^{\text {nd }}$ wave" is creating havoc even in the countries that had quite well managed before - during the $1^{\text {st }}$ wave of Spring 2020. Even with the vaccine, it is quite probable that economic recovery will be postponed to 2022-2023. Would the Eurozone accumulate a historic lag compared to Asia in the pandemy context? Analyses done by the end of September 2020, that is before the $2^{\text {nd }}$ epidemic wave struck Europa, were already showing that the EU and the Eurozone, as some other advanced economies, fared worse in that context. This $2^{\text {nd }}$ wave would quite probably strengthen this lagging.

Keywords: COVID-19 epidemic, $2^{\text {nd }}$ wave, economic collapse, lock-down, economic cost, government support, EU countries.

JEL Classification: D78, E32, E65, G33, I18, J64.

DOI: $10.31737 / 2221-2264-2021-49-1-8$

1. The COVID-19 Shock

With the "the Great Lockdown" imposed in some economies, the world faced a crisis without precedents1. There is a subtle, but distinct link between non-pharmaceutical protective measures taken, like "social distanciation" and lockdowns, and the impact of the COVID-19 induced recession. The analysis done by the IMF (Franks et al.,
2020) shows evidence on the association between lockdowns and economic activity over a sample of up to 52 advanced, emerging markets, and developing economies. Graph 1 displays the correlation between the stringency of lockdowns during the first half of 2020 and the decline in GDP relative to pre-pandemic forecasts (Figure 1). 